\title{
Comperative Overview of Alternative Measures in Different Places
}

\section{PhD Candidate Adrian Leka}

\author{
Faculty of Law, University of Shkoder "Luigj Gurakuqi", Shkoder,Albania,4001 \\ Email: leka-ad@live.com
}

\section{Doi:10.5901/ajis.2014.v3n4p219}

\begin{abstract}
Alternative measures are types of criminal sanctions which give a substitute measure of detention and prison. These are new measures that are being implemented in practice last thirty years, when radical changes were made in the penal system. These are new approaches that enable the execution of the sentence outside the prison premises. The main reasons why I treat alternative measures in our country are that they are new measures which have not been studied much earlier due to the time since here are relatively new measures that are envisaged in the Penal Code changes in 2004 so they need more time during the fundamental analysis and treatment of these measures.Also they are quite interesting and useful to society because they provide positive changes in the penal system, because their purpose is itself enough democratic which has to do with the isolation of a person not convicted of those offenses which are not very dangerous and harmful for the society. This work is divided into eight chapters, each of them deast with important issues. In this study I have dealt with the meaning of the alternative measures, general analysis of the characteristics, such as their types are provided within national and international acts and laws. A special look is made to the studying of alternative measures in Macedonia starting in that order such as the Penal Code provides, as are analyzed according to criminal law by various authors and the problem of their implementation in practice. What makes deeper this issue is the fact that they have researched to find differences and similarities between same types of alternative measures provided by different penal codes, analyzing in particular the countries of the region, Kosovo, Albania and other countries, also I am oriented in determining the types of alternative measures envisaged in our code, the types of alternative measures which have shown a positive effect, comparison of alternative measures imposing other penalties, analyzing alternative measures that are imposed mostly by the courts and the need for our Penal Code to provide or not new kinds of alternative measures that has not done so far, but other countries have, and which have shown a positive effect.
\end{abstract}

\section{The Notion and Understanding of Alternative Measures}

Penalties are generally violent measures envisaged by law, which the court imposes criminal responsibility against the perpetrators of the offense and offender, in order to protect certain values of citizens and society as a whole, and which consist in making or restricting the freedoms and rights of the perpetrator of the offense or the offender. Penal codes in different states provide numerous types of penalties, ranging from the death penalty, sentence of imprisonment, a fine, penalties of up to secondary and alternative.According to their legislation, states have modified sentences in different types, defining the terms and conditions for their pronunciation.

Some new forms of sentences, which have taken place in the Penal Codes and are able to be implemented in practice, being quite efficient, are the alternative measures (sanctions).

Predicting measures (sanctions) as a substitute of alternative sentence with that of imprisonment, is a progressive trend in contemporary criminal law, and at the same time it presents significant reform in concept and system of punitive sanctions because of its fundamental characteristic is the trend of bifurcation, which means splitting in two directions, in:

- Prison sentence for serious offenses

- Penalties and alternative measures for lesser offenses.

With alternative measures we mean suspension for a time and under certain conditions of the sentence imposed. This is a new option which means that a person who has committed the offense of low endangerment, alternative measures may be imposed in accordance with the Penal Code.These measures as are necessary to reduce the use of prison sentences, while at the same time meet the demands of justice in connection with the perpetrator, the victim and society.

Their execution takes place outside the detention premises and bring changes. These new measures which have a positive effect on the improvement, rehabilitation, reeducation of offenders and also prevents that in the future he does not carry again the offense. 


\subsection{Their legal qualification}

Alternative sanctions are not defined at all criminal legislation. There are differences and they are defined as:

- Alternative Sanctions

- Alternative measures, or

- $\quad$ Alternative Measures with prison

Given these definitions we can say that in Macedonia, they are qualified as alternative measures, in Kosovo as alternative punishments and in Albania Penal Code provides as prison alternatives. Eventhough different authors define them differently nevertheless they are the same and mean itself: punishment, control, prevention. If both measures and imposed penalties due to the crime, against the person responsible, after completion of the criminal proceedings that the court imposes, are realized by a special body of competent, have elements of repression and prevention. Alternative measures may be dependent or independent.

Some of the alternatives are pendant nature because the prison sentence exists as main punishment but it will not be executed if the conditions and circumstances set outby law. There are such measures which can be independent when the court pronounces in themselves, because they do not supersede the prison but contain treatment and supervision by competent authority designated.

\subsection{Risks of using alternative measures like replacement of prison}

Alternative measures have advantages and drawbacks. Some of the potential risks identified in European countries are:

- New penalties as alternatives instead of prison sentencing can be dangerous if they are made without fulfilling the conditions prescribed by law.

- Can be present a risk if they are not precisely defined by law for the types of offenses that may have been imposed because they can be misused in various ways by applying for such types of offenses but to which it is their impossible pronunciation of words is usually done for those high risk offenses and for with the worst sanction and this hurts the offenders of other criminals with lower risk dangerousness.

- Mechanisms should be developed to ensure that this process is part of a whole system. For a professional staff should be appointed on a legal basis in order to ensure professional and personal continuity because otherwise we will fail with the entire process.

- A permanent risk represents also the lack of communication with the public because they need to understand its concerns and assure them that work with offenders and is well supervised and is meaningful. This damages the trust of society and citizens because if there is doubt that the process of surveillance is not okay then it presents serious problems for them. All these are strong reasons, which have influenced the award of negative criticism regarding imprisonment, which is executed for more than two centuries in all countries of the world. Although previously envisaged two other types of sentences that do not send the convicted person to prison, such as: a suspended sentence and a fine, is nevertheless not possible reduction even these powerful offenses. As a result this and the aforementioned trend began seeking new alternatives. Such evaluation have enabled the application of measures and alternative sanctions, and regarded as the most effective and best way.

Alternative measures are penalties and criminal sanctions, which have a dual character: prevention, which means protecting society from crime, and oppression consists in punishing the perpetrators of the crime.

Their main aim is to develop the fight against crime, without the executed prison sentence, which means sanction with non insulation measures. These measures are imposed for misdemeanor offenses and less risky, which are considered less serious.

\section{International Acts which Provide the Alternative Measures}

Because the prison punishment is applied in many countries and for a very long time, it still had serious criticism, and therefore the need for extraction of alternative sanctions became necessary. This issue has caused in their forecast attend many countries around the world which precede Western Europe, England, Sweden, Denmark, France, and Italy, and then all other states. Historically, alternative measures were first foreseen in England, in 1970, and then in other countries of Western Europe, such as Sweden, Denmark, France, Italy, and later in the United States.

Special contribution in their approval has given of the VII Congress of the United Nations about crime prevention 
and the treatment of offenders, which was held in Havana in 1990, where it was lounched, the minimum standards of the United Nations rules for noninstitutional measures, (the Tokyo Rules).

These were approved by Resolution of the UN General Assembly on 14 December 1990. At all these conferences was recommended wider acceptance of alternatives to prison, with the aim of social integration of people convicted. Tokyo Rules include a number of alternative sanctions.

\subsection{Alternative sanctions are:}

1. Verbal sentences such as: reprimand, admonition and warning

2. Bail

3. Penalties associated with status

4. Economic sanctions and penalties such as fines with money and daily fines

5. Order for confiscation or expropriation

6. Restitution for the victim or order for compensation

7. Suspended sentence and its different variants

8. Tumult or judicial monitoring

9. Community service work

10. Centered care delivery

11. House arrest

12. Otherwise non-institutional treatment or other combination.

Their prediction shows more favorable opportunities to assist offenders in their integration as successful, and as soon as possible in society.Such documents provide rules and recommendations which have acquired the character of frameworks and universal solutions. Even European rules for alternative sanctions and measures which define standards which will enable different countries more efficient induction of alternative measures in society, as new opportunity of responding to crime. These provisions are very clear on how to behave appropriately in determining the responsible personnel and execution of such measures.

\subsection{Conditions for their imposition}

- The rights and obligations of sentenced persons shall be determined by law

- They must be understood and accepted as are prescribed .

- Each alternative measure must be specified intervally, and the body that implements it must establish limits under the law .

- Type of alternative measures should be imposed in accordance with the type of offense .

- The body that implements them must be a legitimate, act in legal basis, and their powers be defined in a way.

- People who deal with imposition and their implementation should be experienced and professional people .

- Their work must be conducted with oversight by a separate body

- Decision to impose themmus be taken only by the court and no other body .

- The right of appeal may be realized in the judiciary if the perpetrator complains that the decision taken regarding alternative measures is illegal and is contrary to the content of sanctions or alternative measures .

\subsection{International probation services}

Supervision for the implementation of alternative measures to the competent body to realize who has the rights and obligations of every kind. This body is called the probation service. In European countries, the probation service means all activities of proof in criminal justice (social inquiry reports, immediate intervention, activities in the field of sanctions and crime prevention activities, etc.). The following tasks are shared for all European probation services:

- Ensuring information and qualitative assessments to judicial authorities and others to help them with penalties and other decisions - development, organization and supervision of community sanctions and measures, ensuring that they are implemented effectively;

- Provision of assistance, care and after-care practical, social and psychological care;

- Ban offenders not to return to crime, reinforcing their confidence and self-discipline;

- -To contribute to a safer society by encouraging offenders to become law-abiding members of society, 
effectively supervised offenders in order to reduce the opportunity to commit offense again and developing skills which contribute;

- Support of prisoners and providing assistance during the preparations for the release;

- Control and monitoring of the conditions that apply to offenders of the law;

- Provision of assistance to families of offenders to maintain and improve relationships with the offenders and to eliminate the difficulties that may impede integration into society.

\subsection{Local acts and bases for legal determining.}

Besides international acts that have provided alternative punishments and alternative sanctions, is considered resonable that they need to be prescribed with rules and standards with local legal provisions in penal law because the state is embodied the principle of international solidarity that means obligation of states that incorporate the same rules and conditions in penal codes of countries. In this way manifests solidarity in combating the criminal offense or misdemeanor. Although in the Tokyo rules are forseen enough types of alternative sentencing and measures, states have seen reasonable in their legal provisions to include only some of them, not all, being justified by the importance and impact of their implementation.

\section{Comparative Overview of Alternative Measures in Different Places}

These types of criminal sanctions in recent years have begun to be implemented in all countries of the world. In their criminal legislation are included quite different types of alternative sanctions, based on the rules and standards of international instruments. Tokyo Rules have had extensive repertoire of norms and standards and provide multiple types of alternative sanctions, so states in order to separate each have appropriated only for those types which have been more appropriate and necessary.

In the Macedonian Criminal Code are provided these types of alternative measures; conditional sentence, conditional sentence with protective supervision, conditional cessation of criminal procedure, work in community service, house arrest and judicial admonition.

Criminal Code of Kosovo has provided these types of alternative: suspended sentence, conditional sentence with protective supervision, a suspended sentence with an order for compulsory psychiatric treatment, suspended sentence with an order for community service work, and semi-freedom.

The Criminal Code of Albania has provided these types of prison alternatives; fragmentation of imprisonment, suspension of execution of criminal sanctions, replacement forced to perform work in the public interest and advance parole.

In Serbia are provided these types of alternative: working in the public interest bail with protective supervision, bail without protective supervision, judicial admonition, obtaining property and goods conditional sentence.

In Slovenia are prescribed these types of alternative sentences: conditional suspension of prosecution, community service work, suspension of prosecution and judicial admonition.

In Italy are foreseen these types of alternative sanctions: House arrest, premature release, work outside the Institute and half freedom.

Even in other countries are provided such measures so as measures which are common in almost all Criminal Codes are: suspended sentence, judicial admonition and work in the public interest. Comparative Overview regarding these types of measures and alternative sanctions such as: work for the benefit of general, probation (control test), victim compensation, house arrest, electronic monitoring, reduction of prison sentence and commitment to jail parole.

Community service work presents free performing for hours which should be realized over stated time. This measure exists in many countries for many years and there is established tradition such as in: UK, France, Norway, Ireland, Portugal, etc. Community service work in isolation means no criminal perpetrator, because it takes the freedom of movement and also contains the sentence attribute moral, financial and certain other obligations to the injured and society, which he has to fulfill. As far as how much time can be prolonged, depending on different countries not determined and therefore the same is not limited to: Portugal (9-180 hours); Finland (20-200 hours), France, Ireland, Iceland (40-240 hours) Rep.. Czech (50-400 hours) Slovenia (80-240 hours) etc..

Electronic surveillance method is very costly and requires many conditions and circumstances to be achieved well. So far the manner of surveillance and control electronic experiment still carries the Netherlands, and Scotland even though since 1997 has provided the legal provisions has not yet started implementation in practice. 
House arrest enables the execution of imprisonment to become in the house of the perpetrator of the offense. This is option allowed only certain categories of persons such as: self-feeder parents and if he/she has children up to 3 years, is a pregnant woman, is woman after childbirth, is a person over 65 years. This measure can only be imposed for offenses which have short sentence. So far this applies in Switzerland.

Bail means the parole of a convicted person. States do not have the same statutory permitted when this option. In countries such as Austria, England, Portugal, Iceland, France, Germany, Luxembourg has1/2 of the sentence. In countries such as Greece, Norway,

Switzerland, Estonia, America is needed 2/3 or Belgium 1/3 .

\section{References}

Dr.Ismet Salihu, Penal Law, Pristina 2005, p. 432,434,461

Dr. Ragip Halili, Penology, Prishtina 2005

Human rights and prisons, Training Guide on Human Rights for Prison Officials, New York \& Basel, 2005, p. 201,204

Evropski pravila za alternativni sanksii I merki primenuvani vo zaednicata, spisanie nr.1 Skopje (1998) p.183

The Penal Code of the Republic of Macedonia (Official Gazette), Skopje 2004

The Penal Code of Kosovo, UNMIK Regulation 25 July2003, p.18,14

Ragip Halili-Science Penology on Execution of Criminal Sanctions, 2002 p .246 Pristina

Prof. L.Arnaudovski, Bugjarova G., D. Celevski, L.Nanev,Strategie za implementacija MERKI alternativnite us, Shkup 2004

Vlado Kamboski , Krivico pravo opsht del, Shkup 2003 p.725

Prof.Lupco Armaudovski,Grdana Bugjarovska, Dragi Celeski,Llazar Manev Strategija za implementacija na alternativnite merki, Shkup 2004 p. $27-32$

Feasibility study of legislative and structural possibilities of the prison system for the implementation of alternative, European assistance mission to the Albanian justice system ,Tirane 2006 p.18

Study by Euralius European Assistance Mission to the Albanian Justice System, 2006 Tirana

Dr. Ismet Berisha Penal Law (general part), Pristina 2005 fq.441,442

Dr. Naum Shurbanovski , Alternativi na kaznata zatvor, Shkup 2006 p.167

Report from the European Assistance Mission to the Albanian Justice System, Tirana, 2006

Stoimenova Sllagjana , Kriviqen Zakonik, neni 48 Shkup 2006 p. 24 
